Article

\title{
Controlling the Thermal Power of a Wall Heating Panel with Heat Pipes by Changing the Mass Flowrate and Temperature of Supplying Water-Experimental Investigations
}

\author{
Łukasz Amanowicz (iD \\ Institute of Environmental Engineering and Building Services, Poznan University of Technology, 60-965 Poznan, \\ Poland; lukasz.amanowicz@put.poznan.pl
}

Received: 12 October 2020; Accepted: 9 December 2020; Published: 11 December 2020

\begin{abstract}
Renewable energy sources for the purpose of heating buildings cooperate perfectly with so-called low-temperature heating systems. Water loop surface heating systems had been thoroughly tested. In contrast, thermal performance of wall panels with heat pipes have not been fully recognized, yet. The determination of the thermal power as well as the control of panels thermal performance cannot be performed with the methods developed for water loop systems. In this paper, the novel heating panels with heat pipes were tested to analyze the possibility of controlling their performance by changing the mass flowrate of heating water and its temperature. Specific heating power of the investigated panels varies from $16.9 \mathrm{~W} / \mathrm{m}^{2}$ to $93.8 \mathrm{~W} / \mathrm{m}^{2}$ when supplying a water temperature ranging from $35^{\circ} \mathrm{C}$ to $65^{\circ} \mathrm{C}$ and mass flowrate from $10 \mathrm{~g} / \mathrm{s}$ to $47.5 \mathrm{~g} / \mathrm{s}$. Investigations revealed that the thermal performance of the panels is more sensitive to the changes of temperature than to the changes of mass flowrate of supplying water, and thus, should be controlled by changing the supply water temperature at low mass flowrates to obtain a low energy usage of pumps (diminished pressure losses) and good quality of controlling.
\end{abstract}

Keywords: wall-type heating system; heat pipes; thermal characteristics; thermal performance control; low-temperature heating; surface heating; radiant heating; low energy buildings; nearly zero energy building (nZEB)

\section{Introduction}

One of the main aims when erecting buildings is to assure safety and comfort for their users. In the context of climate change and the depletion of non-renewable energy resources (e.g., gas, coal, oil etc.), contemporary construction faces an additional challenge: buildings must be energy-efficient and renewable energy sources should be used for supplying them. In cold and moderate climates, the energy demand for heating exceeds the energy demand for cooling purposes. The forecast of cooling needs increase, described in Ref. [1] (by 7.5 times for residential buildings) may bring some change on this field in the nearest future. For that reason, there is a growing interest in the various methods of natural shading and limiting the influence of solar radiation on thermal comfort in the buildings, which was described in Ref. [2]. Nevertheless, in cold and moderate climates, buildings have to be heated. In order to save primary energy, legal requirements, e.g., in the European Union, have specified that modern buildings need to be well-insulated. Achieving reduced energy consumption for heating is also favored by the air-tightness of the building envelope and ventilation systems with heat recovery, which was described in Ref. [3]. The energy consumption for heating the ventilation air in winter and cooling it in summer can be reduced even further by using earth-to-air heat exchangers to preheat or precool external air $[4,5]$. Another way to reduce the energy consumption of heating systems is 
their hydraulic balancing—currently, more attention is paid to this issue. Ref. [6] has described the importance of proper regulation and zoning of heating installations for energy savings, which resulted in energy savings from $14.6 \%$ to $23.8 \%$, and Ref. [7] revealed that the use of thermostatic valves for radiators can result in energy savings from $7.1 \%$ to $23.3 \%$. The importance of appropriate zoning of the heating system based on radiant ceiling panels was also emphasized in Ref. [8], in addition to the necessity to use appropriate algorithms for controlling their operation in order to obtain thermal comfort of users. On the other hand, thermo-modernization seems to be energetically and economically justified. In Ref. [9], it was shown that retrofitting of a building can result in energy savings of $30 \%$. In a holistic approach, however, it seems to be more justified to use multi-criteria assessment methods, such as, for example, the global cost method, which was presented, for example, in Refs. $[10,11]$ for the purpose of assessing thermo-modernization projects.

Thanks to, among others, the trends, treatments and systems described in the first paragraph of the introduction, the heat demand of contemporary and retrofitted buildings expressed in $\mathrm{W} / \mathrm{m}^{2}$ is small enough to use low-temperature heating systems, especially surface heating (floor, ceiling, wall). The use of solar, wind and ground energy is effective mainly in cooperation with the systems mentioned above. From the Ref. [12], it appears that surface heating is conducive to the feeling of good thermal comfort, especially if it cooperates, in an appropriate way, with the ventilation system. Better thermal comfort of wall heating systems may result from several reasons, but the most important seem to be: (i) preferred way of heat transfer-mainly by radiation, (ii) less asymmetry of thermal radiation between warm internal partitions and cold external partitions of the building, (iii) even distribution of temperature in the room along its entire height. Better thermal comfort of radiant heating systems was raised in Ref. [13], where the authors performed an overview of the usage of such systems in large halls consuming huge amount of energy, or in Ref. [14], where the combined convection-radiant system was tested. Lowering the temperature of the medium supplying the heating system reduces heat losses during its distribution and contributes to obtaining a higher efficiency of popular heat sources: condensing gas boilers (longer period when the condensation occurs) or heat pumps (higher $C O P=$ Coefficient of Performance). The issues of modeling and simulation of various types of surface heating systems based on water loops are commonly tested. Each manufacturer of pipes, mats or wall, floor or ceiling panels has appropriate selection cards based on the calculations of the thermal performance. These data are based on the results of studies such as Refs. [15,16], which focused on the experimental determination of heat transfer coefficients between surface and room. In these systems, water flows through the water loop and further in the building partition under the plaster layer, causing its surface to heat up/cool down. The thermal effect is fairly easy to predict in these systems, if the following data are known: heat conduction resistance of each of the layers of the building partition, heat transfer coefficient from the partition surface and emissivity of the surface (heat exchange by radiation). Ref. [17] proposed a modification of the method for determining the efficiency of underfloor heating recommended by the current standards, achieving an even better convergence between the results of the calculations and experimental tests. More complex systems use a phase change material to accumulate energy and increase the efficiency, as has been described, inter alia, in Refs. $[18,19]$. The review of research on surface heating systems presented above confirmed the existing knowledge of the thermal issues of these types of systems.

Among the innovative radiant heating systems, underfloor heating systems are the most frequently tested, but not only. In Ref. [20], the corrugation of the heating surface aluminum panel was investigated, causing an increase in thermal performance not only due to the larger heat exchange surface, but also as a result of the intensification of heat transfer by natural convection. Experimental investigations of heating panel system presented in Ref. [20] were similar to the present work from the methodological point of view, but they were taken into account a water loop system based on water flowing through the interior of the ceiling panel. In this paper a completely different system is investigated based on the refrigerant closed in heat pipes in wall-type system. In Ref. [21], the authors analyzed the energy and economic performance of the prefabricated electric radiant floor system; the main difference between 
actual investigations is that it is focused on the floor heating and with the usage of the electricity without water and/or refrigerant gas. Infrared (IR) photos presented in Ref. [22] show that the temperature distribution in the electric floor heating system is more uniform than in a water loop system. In Ref. [23], the thermoelectric radiant ceiling panel was tested differing from panels investigated in this paper with the construction: the aluminum ceiling plate was connected with a thermoelectric module that heats it up using electricity. In the devices used in the present investigations, heat is provided to the wall by means of heat pipes heated up by the hot water from the bottom collector. In Refs. [24-26], the capillary tube floor mats were tested, showing the significant annual energy reduction for heating thanks to their thermal characteristics. The heating surface is heated in such devices by micro tubes (capillary) filled with hot water. Capillary tubes were also tested as a device for heating in a ceiling mode, which was presented in Ref. [27]. A novel radiant-convective heating system was tested in Refs. [28,29] as having advantages from both radiant and convective systems. In both systems, heating panels with pipes similar to those investigated in the present paper were not used.

The systems discussed above are based on water loops or electricity, and their operation and the ability to control their efficiency have been thoroughly explored. A different type of surface heating system consists of wall heating panels with heat pipes, investigated in this paper. This system is not very popular and is only just entering the heating equipment market, although heat pipes are widely used in applied heat engineering. One of their main advantages is an ability to work in an aggressive environment and the separation of the clean side of a given process of heat exchange from its dirty side. Usually, this effect cannot be achieved using exchangers sensitive for dirt and aggressive environment such as plate-type, tube-in-tube or shell-tube exchangers. For these reasons, heat pipes have been used, among others, in so-called waste heat recovery systems. In Refs. [30,31], the heat pipe device was presented as an efficient tool for heat recovery during the cooling process of production of steel. In Refs. [32,33], the heat pipe heat exchanger was tested for heat recovery from the laboratory scale ceramic kiln (from exhausted gases to water). The results of the investigations presented in Ref. [34] show that heat pipes can also be used to improve the efficiency of the cooling system in air handling units working in hot and humid climates. Heat pipe heat exchangers were also tested for dehumidifying air in heating, ventilation and air conditioning (HVAC) systems for tropical climates [35,36]. Heat pipe systems in air handling units can also be used to utilize the waste energy to preheat or precool fresh air and as a result diminish the energy consumption for heating and ventilating the building, which was presented, among others, in Ref. [37]. Heat pipe systems are commonly used for harvesting the solar energy as evidenced by numerous research studies on the efficiency, efficiency improvement and the possibility of using them for the purpose of preparing domestic hot water for washing, for example, in Refs. [38-42], to mention only a few. A very interesting application of heat pipes is their usage for heating the pavement in winter using solar energy harvested with the evacuated tube collectors, which was described in Ref. [43]. In Ref. [44], the multi-channel heat pipe system was investigated experimentally and numerically. The main difference between this type of system and the system investigated in this paper is the presence of a common lower and upper collector in the application presented in Ref. [44] and a flat aluminum plate as a heat transfer surface. This kind of heat exchanger is dedicated for some kinds of industrial purposes and the device presented in this study is strictly dedicated for purposes of heating the buildings.

The systems described in the preceding paragraphs present a different use of heat pipes than the system tested in this paper. To the best of the authors' knowledge, no examples of the use of wall panels with heat pipes for building heating purposes have been presented in the literature. This type of surface heating system can, therefore, be considered a niche and innovative. In this paper, a novel wall-type heating panel is investigated experimentally. The lack of results of research on the thermal performance of such systems and the lack of research showing the possibility of controlling their thermal power in order to adjust it to the actual heating demand were indicated in this article as a knowledge gap. This was the reason for undertaking this research, which is aimed at determining the experimental thermal characteristics of an exemplary construction of wall heating panels with heat 
pipes and determining the possibility of controlling their thermal performance by changing the mass flowrate of heating water and/or its temperature.

\section{Materials and Methods}

\subsection{Description of the Investigated Heating Panels}

The structure and principle of the operation of investigated heating panels differ significantly from the systems discussed in the introduction. Figure 1 shows schematically the construction of an exemplary device. In the system of wall panels with heat pipes, heating water from the heat source flows through pipes located at the floor of the heated room. The water supplies a group of panels, divided into loops, similar to a typical floor or wall heating loops. The main difference is that the heating water does not flow through the wall panel and does not come into contact with the partition surface either directly or through the pipes. In the investigated devices there are heat pipes (4, Figure 1) located under the layer of plaster or drywall on the wall. In this particular model, the panel consists of three heat pipes with an internal diameter of $8 \mathrm{~mm}$ filled with refrigerant, connected by a common manifold (2, Figure 1) immersed in the pipe with heating water flowing from the heat source. The working fluid (3, Figure 1) closed in the heat pipes evaporates intensively as a result of heating by the heating water. Its vapors (5, Figure 1) rise spontaneously (by gravity) and are cooled down in the upper part of the panel. Thus, they heat the surface of the partition in which they are installed. Cooling down the refrigerant vapor causes its condensation and the gravitational drainage of the condensate down to the manifold (2, Figure 1). Then, the cycle repeats itself. Heat pipes are responsible for the heat transfer from the heating water to the wall surface and, consequently, to the heated room.

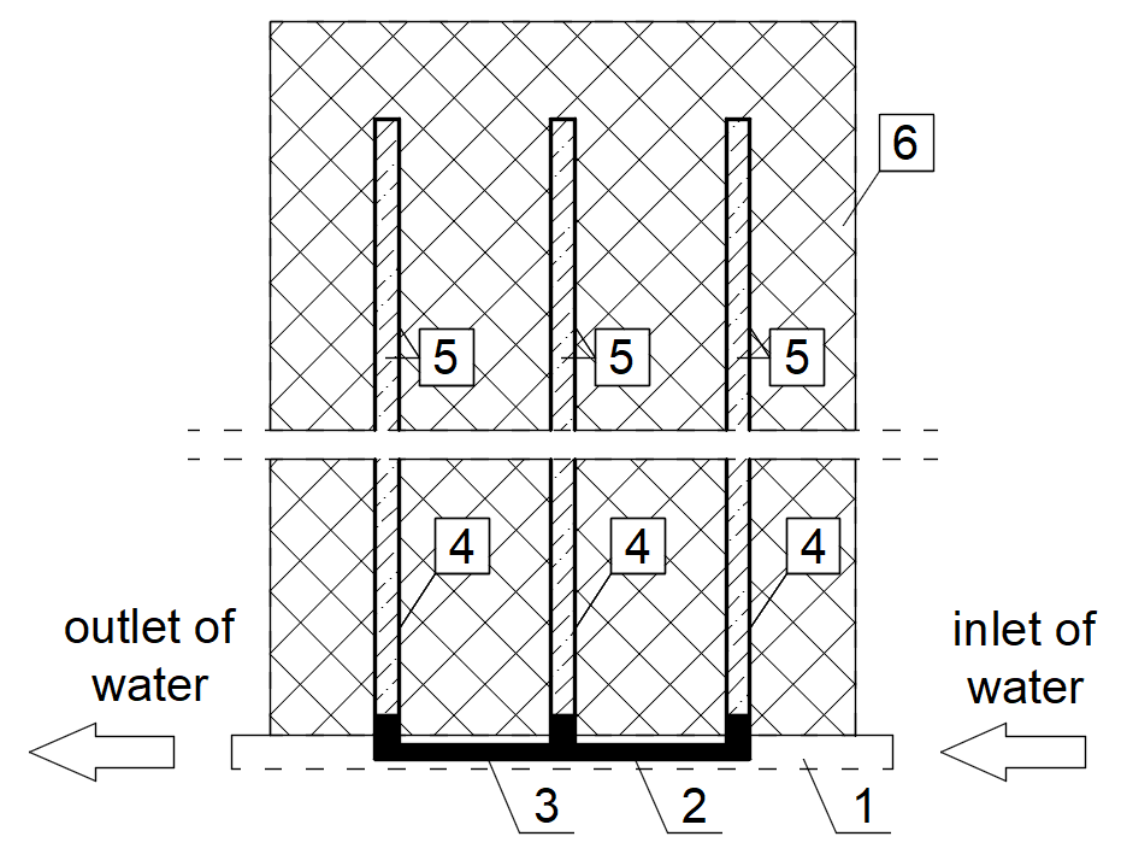

Figure 1. Schema of the investigated system of heating panel with heat pipes to explain the principle of its operation: 1-water pipe, 2-manifold connecting the heat pipes, 3-working fluid in a liquid phase, 4-heat pipe with working fluid, 5-working fluid in the gas phase, 6-aluminum mesh for better heat distribution.

In this study, wall heating panels with heat pipes built under a layer of plasterboard were analyzed. Figure 2 shows a photo of the three panels that were tested. Each panel has three heat pipes, filled with refrigerant, connected at the bottom by a common manifold. This collector is mounted on the axis of a circular pipe, through which the heating water flows from the heat source. The heat supplied to the collector washed with heating water causes intensive evaporation of the working fluid. Working fluid 
vapor rises up along the height of the heat pipes installed in the panel (by gravity) and is cooled down as a result of heat exchange between the heat pipes and the air in the room. In order to distribute heat better over the entire surface of the panel, heat pipes were attached to aluminum mesh. As a result of the cooling of the working fluid vapors, it becomes a liquid and flows down to the collector by gravity, where it heats up, and the cycle repeats itself. During the process of condensation, the temperature of the working fluid is constant.

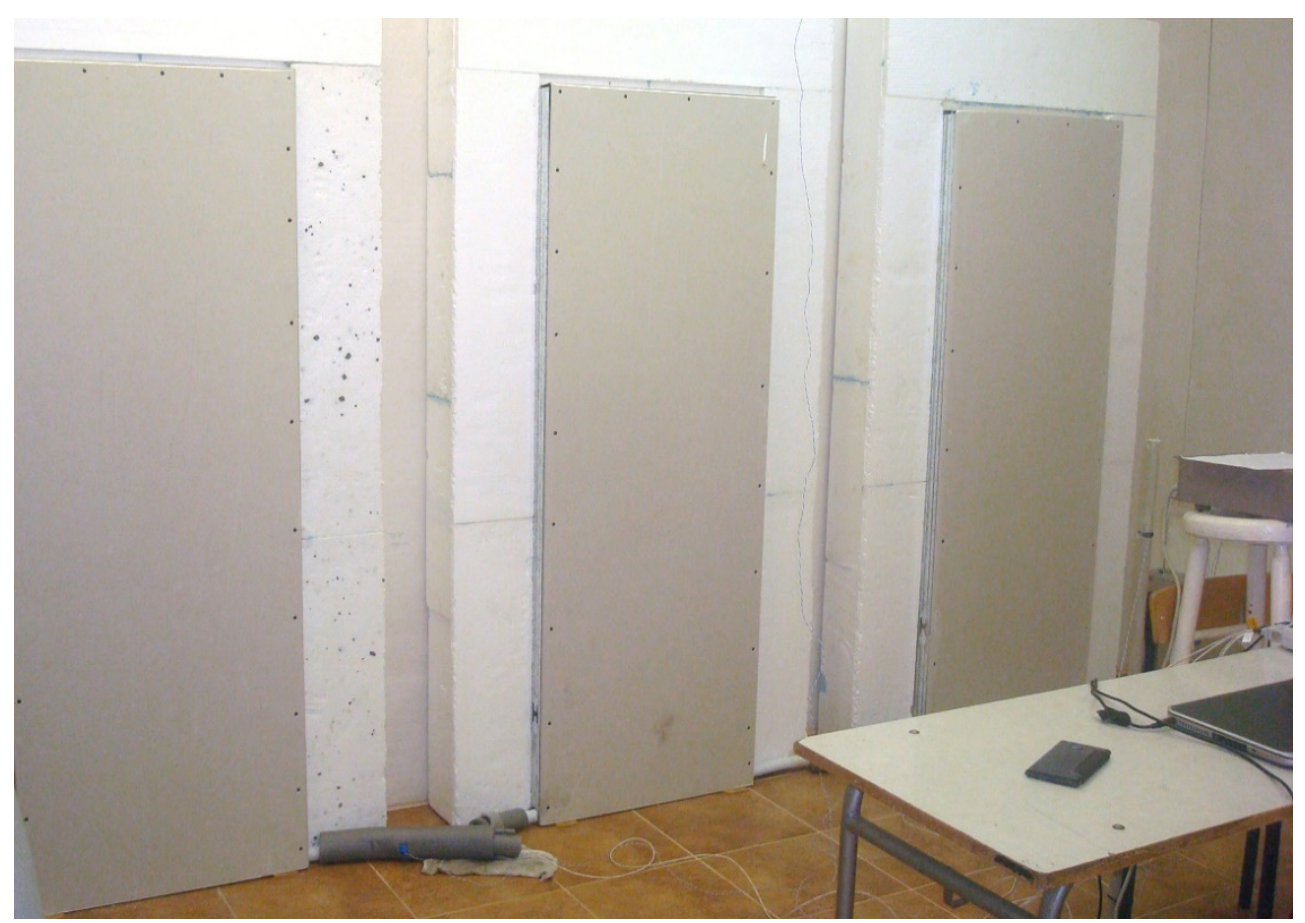

Figure 2. View of the investigated panels in the test chamber.

The movement of the working fluid in the heat pipe is triggered spontaneously (by gravity), so no pumps or other devices powered by electricity or heat are needed for this purpose. As a result, the panels can be perceived as energy-saving, because for their operation, it is only necessary to overcome a slight resistance to water flow through a pipe with a collector immersed in it. The flow coefficient for three investigated panels connected in a row is $k_{v}=1.43 \mathrm{~m}^{3} / \mathrm{h}$, which results in a pressure drop of $0.06 \mathrm{kPa}$ to $1.43 \mathrm{kPa}$, assuming the water mass flowrate correspondingly $m=10 \mathrm{~g} / \mathrm{s}$ to $47.5 \mathrm{~g} / \mathrm{s}$ (range of mass flows tested in this work). Typical pressure drops designed in case of the floor heating systems are about 10-15 (20) kPa. It has to be mentioned that heating panels have to be connected with pipes supplying hot water. For this reason, the total pressure losses would be higher. Assuming the length of the supplying and returning installation in the room $\mathrm{L}=15 \mathrm{~m}$ and internal diameter of pipes $d=0.01 \mathrm{~m}$, the total pressure losses of panels + installations would be $0.8 \mathrm{kPa}$ to $14.93 \mathrm{kPa}$ for $m=10 \mathrm{~g} / \mathrm{s}$ to $47.5 \mathrm{~g} / \mathrm{s}$, correspondingly. It means that for low mass flowrates, heating panels with heat pipes can generate pressure losses much lower than the circuit of the floor heating system, but for higher mass flowrates, total pressure losses can be similar. In the present study, the influence of mass flowrate on the specific thermal power of the panel is tested to judge if it is worth to obtain higher thermal power by using high mass flowrates of the heating water.

\subsection{Experimental Set-Up}

Heating panels obtained for the tests have built-in heat pipes filled with the R134a refrigerant (boiling temperature $-26^{\circ} \mathrm{C}$ ). The manufacturer does not provide information on the amount of refrigerant used or the filling pressure, leaving this information as know-how. From a technological 
point of view, the repeatability of the degree of filling the pipes with refrigerant may not be ideal; hence, the decision was made to test a set of three panels at a time and take the averaged values of their thermal power. The second reason for making this decision is an attempt to reflect their typical working conditions in a group within one water circuit. The third reason and justification for undertaking the tests of a set of three panels is the low temperature drop on a single panel recorded during the initial tests. The measurement of a small temperature difference is burdened with a large relative error. Connecting panels in a row results in (i) more reliable measurement of temperature drop (higher value) and (ii) averaged thermal power for three panels working as a single module in one water loop regardless of the degree of repeatability of production. This simplification is justified due to the small temperature drops on a single panel, which makes the operating parameters of the first and the last panel very similar to each other. It has to be noticed that due to this simplification, the presented averaged results cannot be used to validate the detailed numerical models of the heat exchange taking place in these panels. The purpose of this research is to analyze the sensitivity of the average thermal power of panels to the change of parameters: mass flowrate and temperature of supply water. This simplification was regarded as suitable for achieving this aim.

In order to determine the thermal characteristics of three wall heating panels with heat pipes, experimental studies were carried out. The view of the panels is presented in Figure 2 and the scheme of the experimental set-up is shown in Figure 3. The measuring devices and their accuracy are listed in Table 1. Thermal performance tests consisted of measuring the following quantities:

- $\quad m 1$-heating water mass flowing through the panels during the measurement,

- $\tau$-time of gathering the heating water into a measuring vessel,

- $\quad t 1, t 2, t 3$ - temperature of the water supplying: first, second and third panel, respectively,

- $\quad$ t4-temperature of the water flowing from the third panel,

- tin-air temperature in the test chamber.

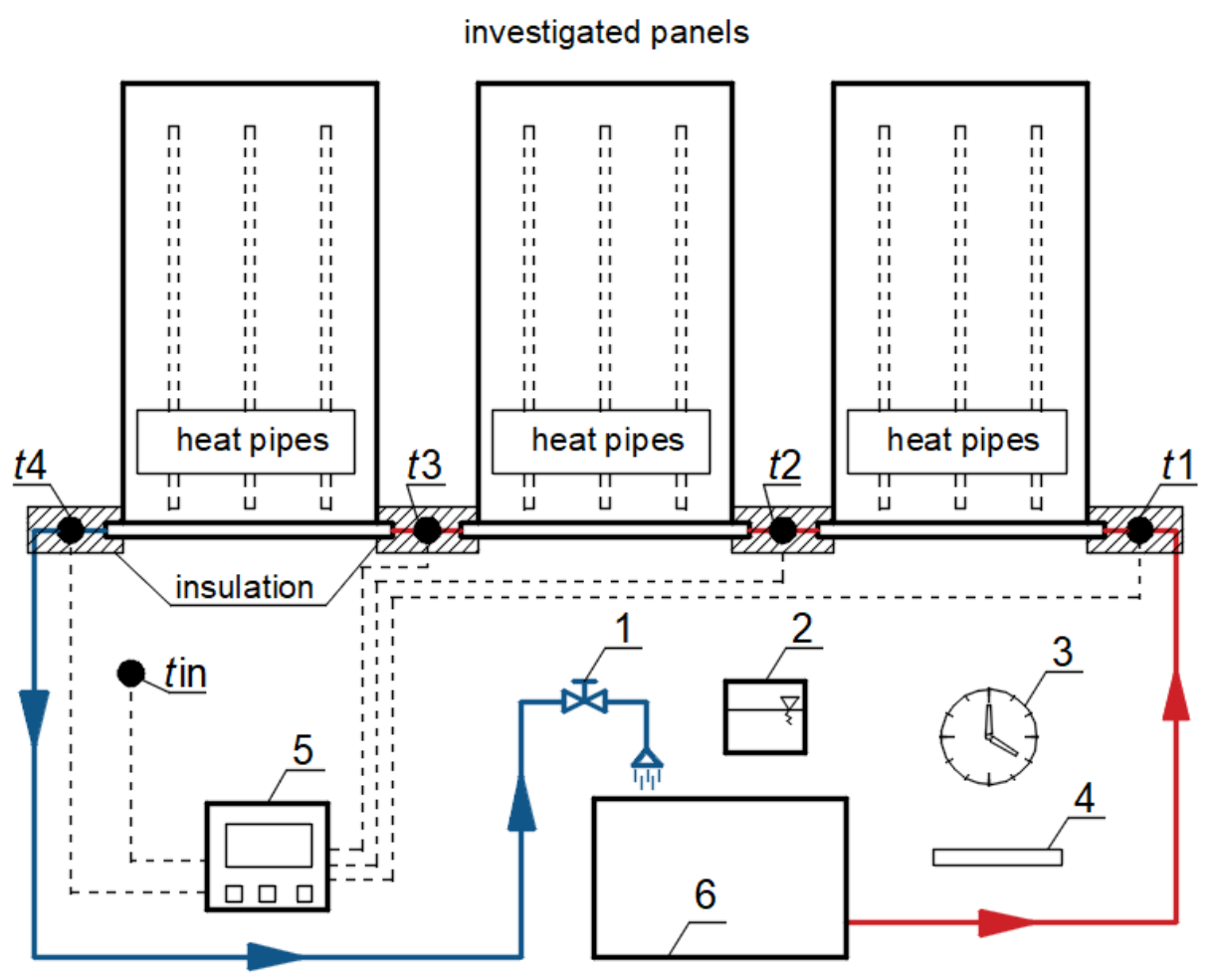

Figure 3. Schema of the experimental set-up: 1-control valve, 2 -water container, 3 -electronic stopwatch, 4-laboratory scale, 5-temperature recorder, 6 -thermostatic bath, $t$-temperature sensors (water supply temperatures: $t 1$-first panel, $t 2$-second panel, $t 3$-third panel, $t 4$-water returning from the third panel; tin-air in the test chamber). 
Table 1. Measuring equipment with its accuracy.

\begin{tabular}{|c|c|c|}
\hline $\begin{array}{c}\text { Measured } \\
\text { Value/Device }\end{array}$ & Measuring Equipment & Accuracy \\
\hline$m 1$ & Laboratory scale Sartorius (4 at Figure 3 ) & $\pm 0.1 \mathrm{~g}$ \\
\hline \multirow{2}{*}{$\tau$} & Electronic stopwatch & $\pm 0.01 \mathrm{~s}$ \\
\hline & $\begin{array}{l}\text { Taking into account the human reflex as a factor decreasing the } \\
\text { accuracy of time measurement with a stopwatch }\end{array}$ & $\pm 0.2 \mathrm{~s}$ \\
\hline$t 1-t 4$ & T-type thermocouples with plug for Omega temperature & \multirow{2}{*}{ $\pm 0.1^{\circ} \mathrm{C}$} \\
\hline tin & Recorder (5 at Figure 3) & \\
\hline thermostatic bath & $\begin{array}{l}\text { Hubner thermostatic bath for heating and cooling with circulation } \\
\text { pomp. Accuracy means precision of temperature stabilization }\end{array}$ & $\pm 0.05^{\circ} \mathrm{C}$ \\
\hline
\end{tabular}

The length of the pipes connecting the panels (between them) was equal to $0.5 \mathrm{~m}(50 d, d=0.01 \mathrm{~m})$. Pipes were insulated with typical polyethylene foam of a diameter of $0.022 \mathrm{~m}$ (thickness of the insulation layer was $0.009 \mathrm{~m}, \lambda=0.040 \mathrm{~W} / \mathrm{m} / \mathrm{K})$. Due to the short length of the connecting sections and their thermal insulation, it was assumed that the heat losses in these sections are negligible for the purpose of determining the intensity of the influence of the supply water mass flowrate and temperature on the thermal efficiency of the panels. The bottom side of the panel (manifold) was insulated with PE foam of a thickness $0.009 \mathrm{~m}$. Heat losses from the manifold to the room were not calculated/estimated in the research, because they were considered negligible (thanks to the insulation) and treated as a part of the heating power of the panel affecting the heating of air in the room as rest of the area of the panel.

The side surfaces and the rear surface of the panel were insulated with $15 \mathrm{~cm}$ thick polystyrene ( $\lambda=0.040 \mathrm{~W} / \mathrm{m} / \mathrm{K}$, thermal resistance $\left.R=3.75 \mathrm{~m}^{2} \mathrm{~K} / \mathrm{W}\right)$. For this reason, the heat losses from the rear wall of the panels were considered negligible.

The mass flowrate $(\mathrm{m})$ of water flowing through the panels was determined with the weight method:

$$
m=\frac{m 1}{\tau}(\mathrm{g} / \mathrm{s})
$$

where $m 1$ is the mass of water gathered to a measuring vessel and $\tau$ is a time of gathering the water.

The specific power of each panel $\left(q_{i}\right.$, where $i=1,2$ or 3 ) was determined with the knowledge of the specific heat of water, which was assumed as $c_{w}=4190 \mathrm{~J} / \mathrm{kg} / \mathrm{K}$ :

$$
\begin{aligned}
& q_{1}=\frac{m \cdot c_{w} \cdot(t 1-t 2)}{A}\left(\mathrm{~W} / \mathrm{m}^{2}\right) \\
& q_{2}=\frac{m \cdot c_{w} \cdot(t 2-t 3)}{A}\left(\mathrm{~W} / \mathrm{m}^{2}\right) \\
& q_{3}=\frac{m \cdot c_{w} \cdot(t 3-t 4)}{A}\left(\mathrm{~W} / \mathrm{m}^{2}\right)
\end{aligned}
$$

where $A$ is the area of the panel $=0.6 \times 1.7=1.02 \mathrm{~m}^{2}$.

The constant temperature of the water supply in the first panel was maintained with an accuracy of $\pm 0.05 \mathrm{~K}$ by means of a thermostatic bath with an integrated circulation pump. Due to the relatively low heating power of the tested wall panels, the thermostatic bath was placed inside the climatic chamber, which had a negligible effect on the temperature inside the chamber and on the stability of the measurement conditions.

In the study, a climatic chamber was used. This chamber was described in detail in the article on the study of the efficiency of ceiling heating and cooling panels [22]. The chamber was made in accordance with the guidelines of the EN 14240 standard for cooling ceilings testing and ISO 18566-218 for radiant panels testing. The dimensions of the chamber and its most important parameters are shown in Figure 4. 


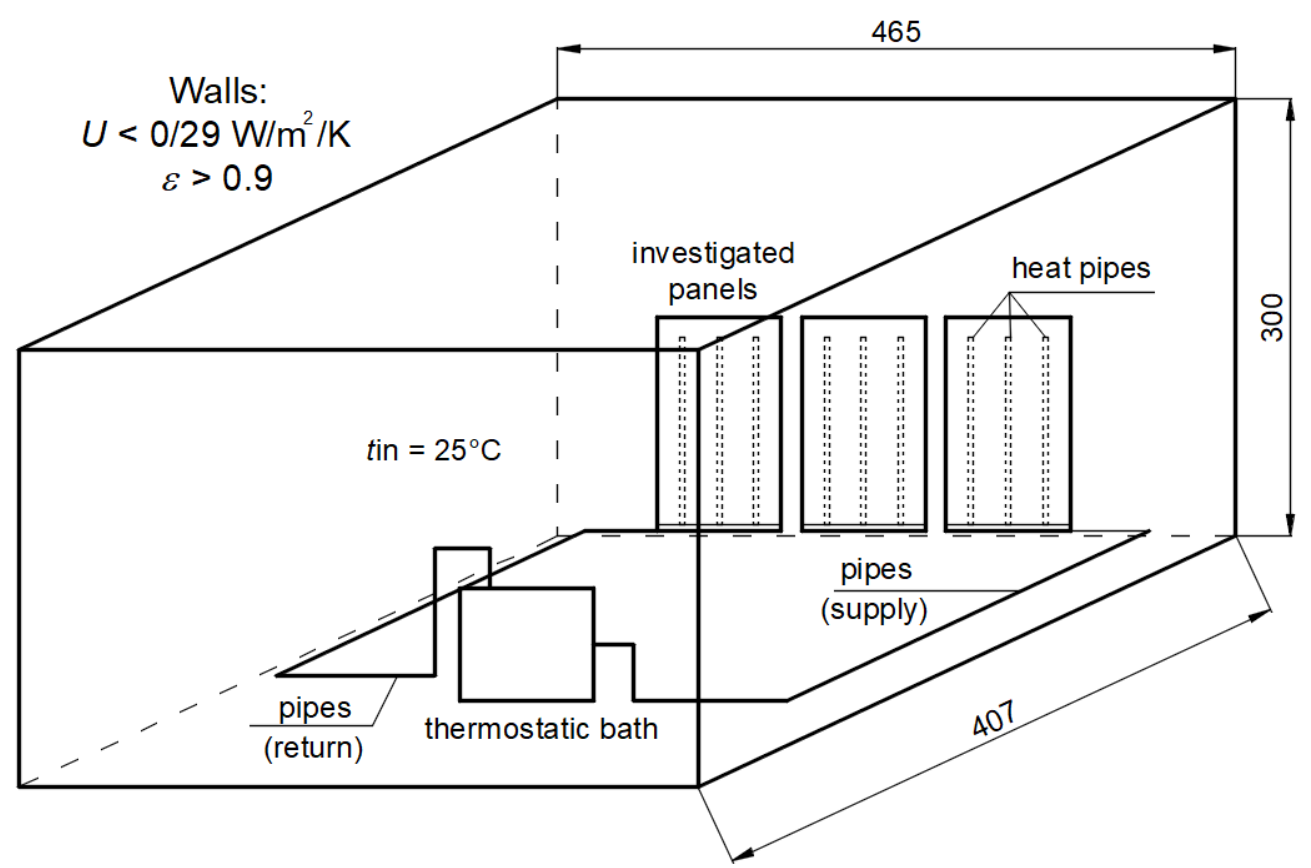

Figure 4. Schema and main parameters of test chamber. Dimensions are given in $\mathrm{cm}$.

The research was carried out for three mass streams of heating water, e.g., $10 \mathrm{~g} / \mathrm{s}, 30 \mathrm{~g} / \mathrm{s}$ and $47.5 \mathrm{~g} / \mathrm{s}$ and four temperatures of the heating water supplied to the first panel $t 1: 35^{\circ} \mathrm{C}, 45^{\circ} \mathrm{C}, 55^{\circ} \mathrm{C}$ and $65^{\circ} \mathrm{C}$.

\section{Results}

\subsection{Specific Thermal Power of the Investigated Panels}

The results of measurements are presented in Table 2 and in Figure 5. The specific thermal power $q_{i}$ for $i$-panel $=1,2$ or 3 was calculated from the Equations (2)-(4). The medium value of a single panel specific thermal power was calculated as follows:

$$
q \mathrm{~m}=\frac{m \cdot c_{w} \cdot(t 1-t 4)}{3 \cdot A}\left(\mathrm{~W} / \mathrm{m}^{2}\right)
$$

Table 2. Results of the measurements and specific heating power calculations.

\begin{tabular}{|c|c|c|c|c|c|c|c|c|c|}
\hline$m(\mathrm{~g} / \mathrm{s})$ & $t 1\left({ }^{\circ} \mathrm{C}\right)$ & $\begin{array}{l}\Delta t 1=t 1 \\
-t 2(\mathrm{~K})\end{array}$ & $\begin{array}{l}\Delta t 2=t 2 \\
-t 3(\mathrm{~K})\end{array}$ & $\begin{array}{l}\Delta t 3=t 3 \\
-t 4(\mathrm{~K})\end{array}$ & $\begin{array}{c}q 1 \\
\left(\mathrm{~W} / \mathrm{m}^{2}\right)\end{array}$ & $\begin{array}{c}q^{2} \\
\left(\mathrm{~W} / \mathrm{m}^{2}\right)\end{array}$ & $\begin{array}{c}q 3 \\
\left(\mathrm{~W} / \mathrm{m}^{2}\right)\end{array}$ & $\underset{\left(W / m^{2}\right)}{q m}$ & $\Delta$ \\
\hline 10.22 & 35.03 & 0.41 & 0.42 & 0.38 & 17.2 & 17.6 & 16.0 & 16.9 & $6 \%$ \\
\hline 30.71 & 35.06 & 0.16 & 0.19 & 0.17 & 20.2 & 24.6 & 20.8 & 21.9 & $12 \%$ \\
\hline 47.86 & 35.05 & 0.10 & 0.12 & 0.10 & 19.7 & 23.6 & 19.7 & 22.9 & $12 \%$ \\
\hline 10.18 & 45.06 & 0.87 & 0.92 & 0.75 & 36.4 & 38.7 & 31.4 & 35.5 & $12 \%$ \\
\hline 29.74 & 44.99 & 0.34 & 0.40 & 0.32 & 41.5 & 48.3 & 39.7 & 43.2 & $12 \%$ \\
\hline 47.36 & 45.03 & 0.20 & 0.23 & 0.20 & 38.9 & 44.7 & 38.9 & 44.4 & $10 \%$ \\
\hline 9.99 & 55.06 & 1.31 & 1.39 & 1.12 & 53.5 & 57.0 & 45.7 & 52.1 & $12 \%$ \\
\hline 30.13 & 55.05 & 0.46 & 0.55 & 0.49 & 56.9 & 68.1 & 60.6 & 65.8 & $10 \%$ \\
\hline 47.33 & 55.04 & 0.33 & 0.39 & 0.33 & 65.1 & 75.8 & 64.2 & 71.0 & $11 \%$ \\
\hline 10.12 & 64.98 & 1.84 & 1.96 & 1.66 & 76.5 & 81.5 & 68.8 & 75.6 & $9 \%$ \\
\hline 29.84 & 65.04 & 0.71 & 0.77 & 0.69 & 87.0 & 94.4 & 84.6 & 90.9 & $6 \%$ \\
\hline 47.24 & 64.99 & 0.44 & 0.53 & 0.44 & 85.4 & 101.9 & 85.4 & 93.8 & $12 \%$ \\
\hline
\end{tabular}




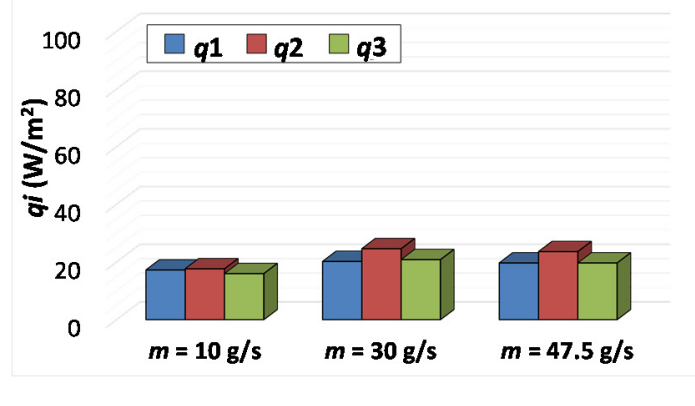

(a)

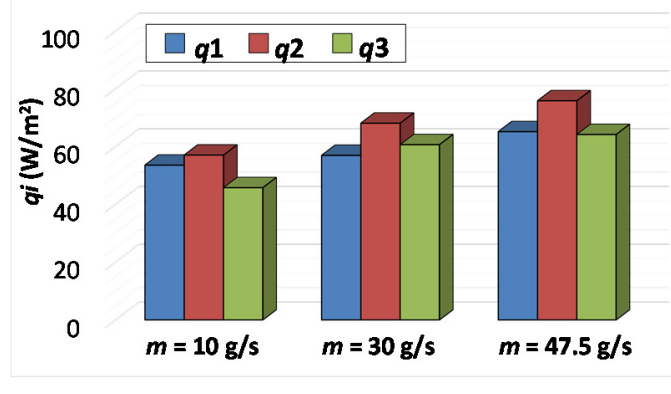

(c)

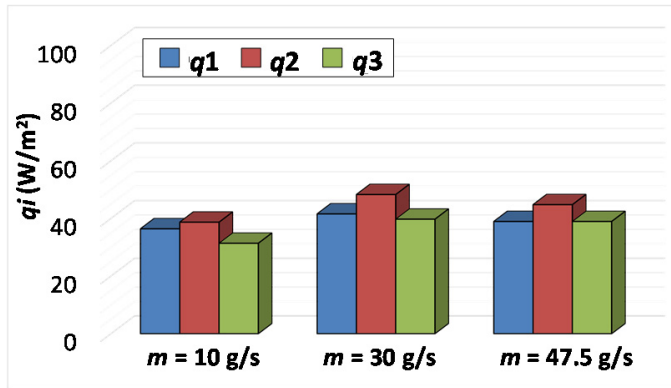

(b)

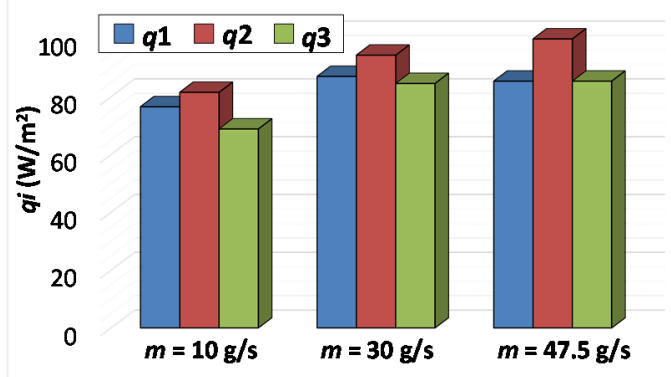

(d)

Figure 5. Specific thermal power $q$ in $\left(\mathrm{W} / \mathrm{m}^{2}\right)$ of each " $i$ " heating panel $(i=1,2$ or 3$)$ when supplying a water temperature of: (a) $t 1=35^{\circ} \mathrm{C},(\mathbf{b}) t 1=45^{\circ} \mathrm{C}$, (c) $t 1=55^{\circ} \mathrm{C}$, (d) $t 1=65^{\circ} \mathrm{C}$.

The maximum difference between medium value of specific heating power was calculated as follows:

$$
\Delta=\frac{\max (q i-q \mathrm{~m})}{q \mathrm{~m}} \cdot 100 \%
$$

The results show that specific heating power of the single panel varies from $16.9 \mathrm{~W} / \mathrm{m}^{2}$ to $93.8 \mathrm{~W} / \mathrm{m}^{2}$ when supplying water temperatures ranging from $35^{\circ} \mathrm{C}$ to $65^{\circ} \mathrm{C}$ and a mass flowrate from $10 \mathrm{~g} / \mathrm{s}$ to 47.5 $\mathrm{g} / \mathrm{s}$. The higher mass flowrate and higher temperature of supplying water, the highest specific thermal power of the panel. The results show that the measured temperature drop at a single panel varies from $0.1 \mathrm{~K}$ to $1.96 \mathrm{~K}$ and depends mainly on the mass flowrate. The lowest values of the temperature drop were obtained for higher mass flowrates and the highest for lower ones.

Thermal power of the middle panel $(q 2)$ is always higher than other panels. This may be due to different refrigerant pressures in the heat pipes or other reasons related to a lack of perfect repeatability during the panel manufacturing process. As the details of the production process remain the know-how of the manufacturer, it cannot be settled in this work. However, it is not necessary to achieve the aim of this work consisting of the assessment of the impact of the temperature and mass flow of water supplying panels on their thermal performance in the context of controlling their thermal power in order to adapt it to the current needs. The results revealed the need for a more in-depth analysis of the design of the panels and heat pipes, in particular regarding the influence of the type of refrigerant, its pressure and panel production repeatability, which was indicated as an inspiration for future research in the discussion section of this paper. In further research, the average values of specific thermal power will be used to present its dependence on the parameters: mass flowrate and temperature of supplied water. This simplification is justified to be done for the purposes of sensitive analysis presented in this study. It was measured that the temperature drop at a single panel is relatively small, which makes the operating parameters of the first and the last panel very similar to each other. The maximum difference between the medium value of a specific thermal power and that 
measured for a single panel is not bigger than $12 \%$, so the mean value of the thermal power taken from three panels was considered representative from the point of view of achieving the goal of the work.

\subsection{The Dependence of the Specific Thermal Power on the Mass Flow of Heating Water}

The test results are shown in Figure 6. The water flowrate was changed for the same temperature of the heating water supplied to the first panel $(t 1)$ and $m=10 \mathrm{~g} / \mathrm{s}, 30 \mathrm{~g} / \mathrm{s}$ or $47.5 \mathrm{~g} / \mathrm{s}$.

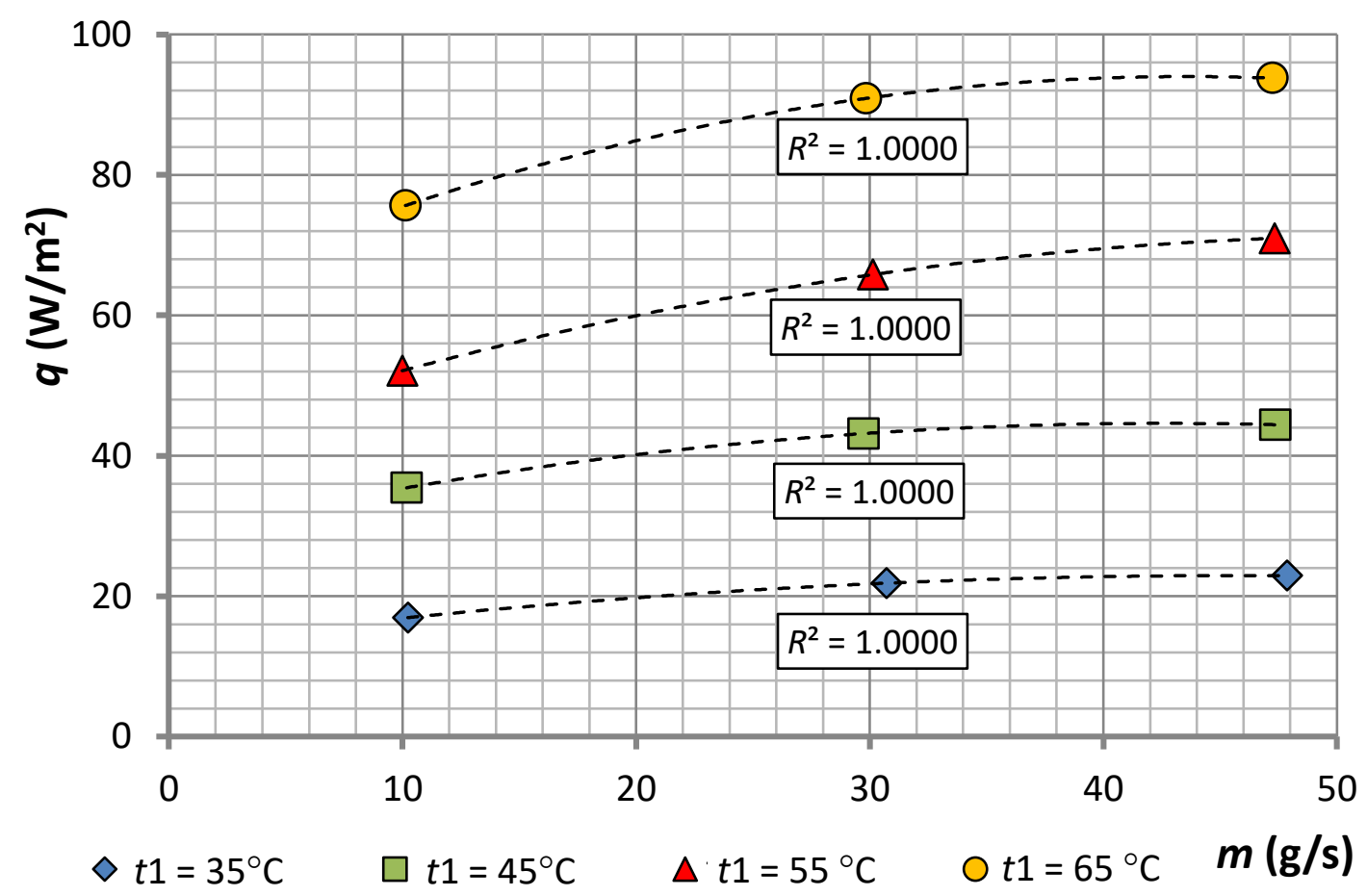

Figure 6. Specific thermal power $q\left(\mathrm{~W} / \mathrm{m}^{2}\right)$ of the panel as a function of mass flowrate $m(\mathrm{~g} / \mathrm{s})$ of heating water for different temperatures of water supply for the first panel $t 1\left({ }^{\circ} \mathrm{C}\right)$, tin $=25^{\circ} \mathrm{C}$.

The range of obtained specific thermal power is presented in Table 3 as well as the percentage increase of $q$ resulting from changing water mass flowrate from the minimum to the maximum.

Table 3. The range of specific thermal power $q\left(\mathrm{~W} / \mathrm{m}^{2}\right)$ obtained for different temperature of water supply for the first panel $t 1\left({ }^{\circ} \mathrm{C}\right)$. The highest values were obtained for $m=47.5 \mathrm{~g} / \mathrm{s}$ and the lowest for $m=10 \mathrm{~g} / \mathrm{s}$.

\begin{tabular}{ccc}
\hline $\boldsymbol{t 1}\left({ }^{\circ} \mathbf{C}\right)$ & $\boldsymbol{q}\left(\mathbf{W} / \mathbf{m}^{2}\right)$ & $\boldsymbol{\Delta}$ \\
\hline 35 & $16.9-22.9$ & $+36 \%$ \\
45 & $35.5-44.4$ & $+25 \%$ \\
55 & $52.1-71.0$ & $+36 \%$ \\
65 & $75.6-93.8$ & $+24 \%$ \\
\hline
\end{tabular}

The relationship between a specific thermal power $(q)$ of the panel and the mass flowrate $(m)$ of the heating water was approximated with the function $y=a x^{2}+b x+c$, obtaining the matching coefficient $R^{2}$, which equals to 1 , which means that assumed type of approximation fits the experimental data exactly for the given temperature of the supplied water $(t 1)$ in the range of investigated cases (accurate for $m=10$ to $47.5 \mathrm{~g} / \mathrm{s}$ ):

$$
\begin{aligned}
& q\left(t 1=35{ }^{\circ} \mathrm{C}\right)=-0.0047 m^{2}+0.4350 m+12.9844\left(\mathrm{~W} / \mathrm{m}^{2}\right) \\
& q\left(t 1=45^{\circ} \mathrm{C}\right)=-0.0087 m^{2}+0.7400 m+28.8294\left(\mathrm{~W} / \mathrm{m}^{2}\right)
\end{aligned}
$$




$$
\begin{aligned}
& q\left(t 1=55^{\circ} \mathrm{C}\right)=-0.0102 m^{2}+1.0879 m+42.2571\left(\mathrm{~W} / \mathrm{m}^{2}\right) \\
& q\left(t 1=65^{\circ} \mathrm{C}\right)=-0.0164 m^{2}+1.4310 m+62.8164\left(\mathrm{~W} / \mathrm{m}^{2}\right)
\end{aligned}
$$

\subsection{The Dependence of the Specific Thermal Power on the Temperature of the Heating Water}

The test results are shown in Figure 7. For the same heating water flowrate $(m)$, its temperature was changed in the range $t 1=35^{\circ} \mathrm{C}, 45^{\circ} \mathrm{C}, 55^{\circ} \mathrm{C}$ or $65^{\circ} \mathrm{C}$.

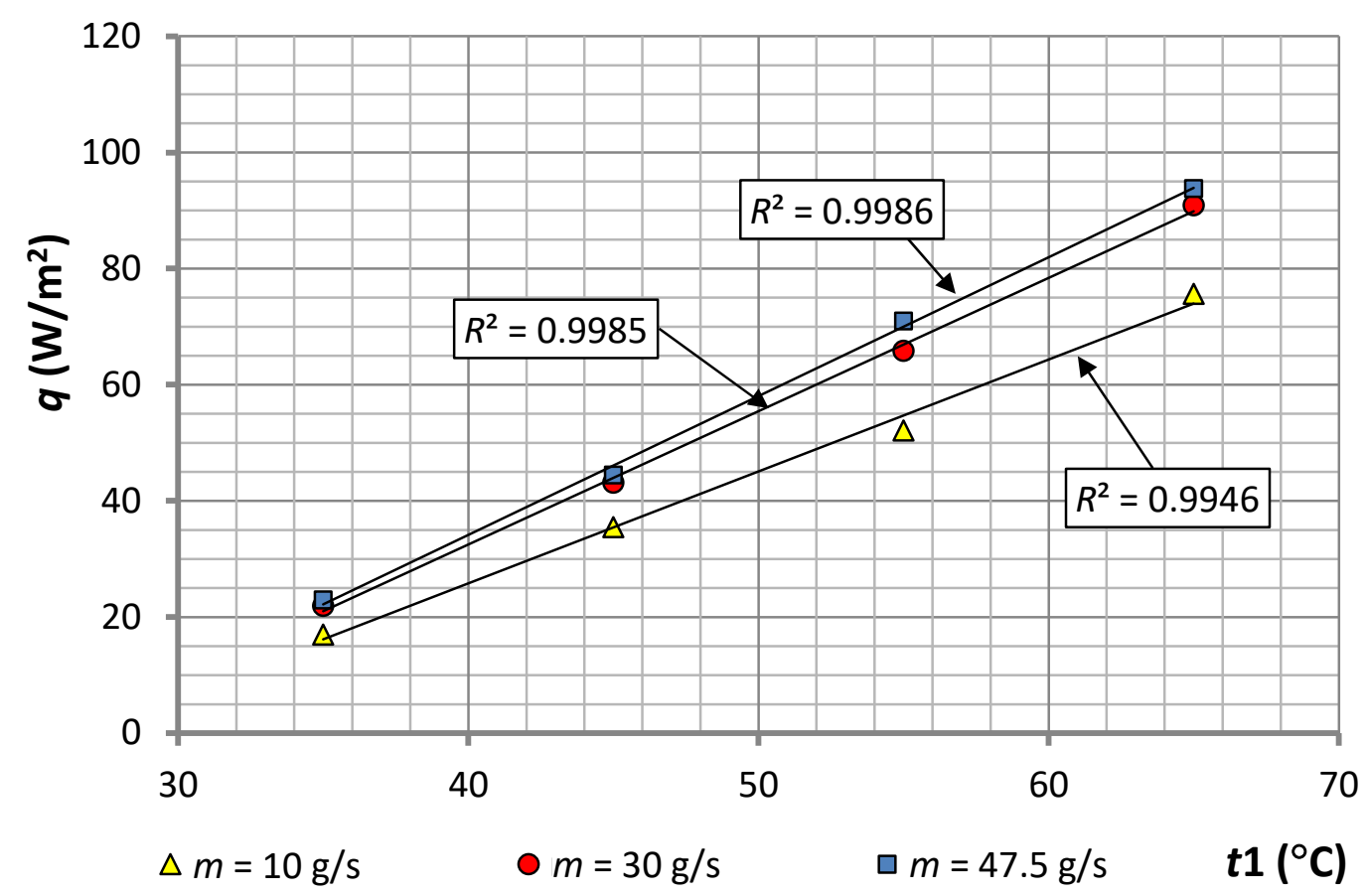

Figure 7. Specific thermal power $q\left(\mathrm{~W} / \mathrm{m}^{2}\right)$ of the panel as a function of mass flowrate $m(\mathrm{~g} / \mathrm{s})$ of heating water for different temperatures of water supply for the first panel $t 1\left({ }^{\circ} \mathrm{C}\right)$, tin $=25^{\circ} \mathrm{C}$.

The results show that the relationship between specific thermal power of the panel and the mass flowrate of the heating water is linear in the investigated range of the water temperature. This is indicated by the value of the matching coefficient $R^{2}$, which in each case is very close to 1 , which means that the assumed type of approximation fits the experimental data almost exactly. The range of obtained specific thermal power is presented in Table 4 as well as the percentage increase of $q$ that resulted from changing the heating water temperature from the minimum to the maximum.

Table 4. The range of specific thermal power $q\left(\mathrm{~W} / \mathrm{m}^{2}\right)$ obtained for different mass flowrates $m(\mathrm{~g} / \mathrm{s})$. The highest values were obtained for $t 1=65^{\circ} \mathrm{C}$ and the lowest for $t 1=35^{\circ} \mathrm{C}$.

\begin{tabular}{ccc}
\hline$m(\mathrm{~g} / \mathrm{s})$ & $\boldsymbol{q}\left(\mathbf{W} / \mathbf{m}^{2}\right)$ & $\Delta$ \\
\hline 10 & $16.9-75.6$ & $+374 \%$ \\
30 & $21.9-90.9$ & $+316 \%$ \\
47.5 & $22.9-93.8$ & $+309 \%$ \\
\hline
\end{tabular}

The results of the investigations can be approximated with good accuracy with the following formulas, representing the relation between the specific thermal power of the panel and the temperature of heating water $(t 1)$ in $\left({ }^{\circ} \mathrm{C}\right)$ for a given mass flowrate of water $(m)$ in the range of investigated cases (accurate for $t 1=35^{\circ} \mathrm{C}$ to $65^{\circ} \mathrm{C}$ ):

$$
q(m=10 \mathrm{~g} / \mathrm{s})=1.927 \cdot t 1-51.321\left(\mathrm{~W} / \mathrm{m}^{2}\right)
$$




$$
\begin{gathered}
q(m=30 \mathrm{~g} / \mathrm{s})=1.391 \cdot t 1-61.524\left(\mathrm{~W} / \mathrm{m}^{2}\right) \\
q(m=47.5 \mathrm{~g} / \mathrm{s})=2.297 \cdot t 1-59.429\left(\mathrm{~W} / \mathrm{m}^{2}\right)
\end{gathered}
$$

\section{Discussion}

\subsection{Results Discussion}

The analysis of the experimentally determined thermal characteristics of wall heating panels with heat pipes is aimed at assessing the possibility of controlling the efficiency of this type of devices by changing the heating water mass flowrate and/or its temperature.

It can be noticed from Figure 5 that the specific power increases with increasing mass flowrate. The growth rate is higher at the beginning, starting from the lowest mass flowrates of heating water and lower for higher mass flowrates. For example, for the temperature of the water supply in the first panel $t 1=35^{\circ} \mathrm{C}$, the change of water mass flowrate from $10 \mathrm{~g} / \mathrm{s}$ to $30 \mathrm{~g} / \mathrm{s}$ (by $20 \mathrm{~g} / \mathrm{s}$ ) results in an increase of the specific thermal power from $16.9 \mathrm{~W} / \mathrm{m}^{2}$ to $21.9 \mathrm{~W} / \mathrm{m}^{2}$ (by $30 \%$ ), while the change in water mass flowrate from $30 \mathrm{~g} / \mathrm{s}$ to $47.5 \mathrm{~g} / \mathrm{s}$ (by $17.5 \mathrm{~g} / \mathrm{s}$ ) results in an increase of the specific thermal power from $21.9 \mathrm{~W} / \mathrm{m}^{2}$ to $22.9 \mathrm{~W} / \mathrm{m}^{2}$ (by $5 \%$ ). For the temperature of the water supply of the first panel $t 1=65^{\circ} \mathrm{C}$, the increasing water mass flowrate from $10 \mathrm{~g} / \mathrm{s}$ to $30 \mathrm{~g} / \mathrm{s}$ (by $20 \mathrm{~g} / \mathrm{s}$ ) results in an increase of the specific thermal power from $75.6 \mathrm{~W} / \mathrm{m}^{2}$ to $90.9 \mathrm{~W} / \mathrm{m}^{2}$ (by $20 \%$ ), while a change in the water mass flowrate from $30 \mathrm{~g} / \mathrm{s}$ to $47.5 \mathrm{~g} / \mathrm{s}$ (by $17.5 \mathrm{~g} / \mathrm{s}$ ) results in the increase of specific thermal power from $90.9 \mathrm{~W} / \mathrm{m}^{2}$ to $93.8 \mathrm{~W} / \mathrm{m}^{2}$ (by $3 \%$ ).

It can also be noticed that for the lowest temperature of the water supply of the first panel, the absolute increase in specific thermal power of the panel due to the increase of water mass flowrate is lower than the analogous increase for the highest temperature (see Figure 6). For example, for the temperature of the water supply of the first panel $t 1=35^{\circ} \mathrm{C}$, the change of the water mass flowrate from $10 \mathrm{~g} / \mathrm{s}$ to $47.5 \mathrm{~g} / \mathrm{s}$ results in an increase of the specific thermal power from $16.9 \mathrm{~W} / \mathrm{m}^{2}$ to $22.9 \mathrm{~W} / \mathrm{m}^{2}$ (by $6.0 \mathrm{~W} / \mathrm{m}^{2}$ ) and for $t 1=65^{\circ} \mathrm{C}$ from $75.6 \mathrm{~W} / \mathrm{m}^{2}$ to $93.8 \mathrm{~W} / \mathrm{m}^{2}$ (by $18.2 \mathrm{~W} / \mathrm{m}^{2}$ ). The percentage increase in the specific thermal power of the panel due to the increase of water mass flowrate is lower for the highest water temperature than the analogous increase for the lowest temperature. For $t 1=35^{\circ} \mathrm{C}$, the specific thermal power increases by $36 \%$, and for $t 1=65^{\circ} \mathrm{C}$ by $24 \%$.

\subsection{Application of the System for Heating the Buildings}

The specific thermal power of the investigated panels is quite high in the context of contemporary low-energy buildings. In the transitional seasons, when the outside air temperature is much higher than the nominal temperature assumed for the design of central heating systems, these panels will have to be supplied with water of a relatively low temperature range of $30-40{ }^{\circ} \mathrm{C}$. This means that they will cooperate best with low-temperature heat sources, such as heat pumps or condensing boilers. If, for example, non-condensing gas or solid fuel boilers are used, obtaining such a low temperature of the supply water to the panels will either be impossible or will require the use of a special system of mixers to lower the temperature of the supply water and increase the temperature of the return water.

The specific thermal power of the tested panels may be sufficient to heat low-energy buildings, but in the case of old-type buildings with high heat demand, there may be a lack of wall surfaces on which heating panels will be placed to cover the heating needs. It should be emphasized that in the case of ceiling or floor heating, more space for the heating system is available, because the walls are more often covered with furniture than ceilings or floors, and the window area in the external walls additionally reduces the space available for mounting the panels. This means that this type of system can be used mainly in buildings with low heating power demand (e.g., passive house or nZEB = nearly zero energy buildings). Old buildings will require a high supply water temperature, so renewable solar energy or heat pumps cannot be used. For these reasons, it seems that the presented wall heating panels should be used, especially in energy-efficient buildings. 
The comparison between specific thermal power of the investigated novel heating panels with heat pipes and the thermal performance of the traditional heating systems is presented in Table 4 . Panel radiators, floor heating systems, water loop wall-type heating systems and wall heating panels with heat pipes are compared. The value of $\Delta$ in Table 5 is the percentage difference between $q\left(\mathrm{~W} / \mathrm{m}^{2}\right)$ of the given system under the given conditions and thermal power of the system investigated in this paper (wall heating panels with heat pipes) obtained for a mass flowrate $m=30 \mathrm{~g} / \mathrm{s}$ and with a water supply temperature of $55^{\circ} \mathrm{C} ; 65.8 \mathrm{~W} / \mathrm{m}^{2}$ was assumed as a reference value for comparisons.

Table 5. Comparison of the specific thermal power $q\left(\mathrm{~W} / \mathrm{m}^{2}\right)$ that is possible to obtain with various heating systems.

\begin{tabular}{|c|c|c|}
\hline System & $q\left(\mathrm{~W} / \mathrm{m}^{2}\right)$ & $\Delta$ \\
\hline Wall heating panels with heat pipes for $m=10 \mathrm{~g} / \mathrm{s}$ and $t 1=55^{\circ} \mathrm{C}, t_{\text {room }}=25^{\circ} \mathrm{C}$ & 65.8 & $0 \%$ \\
\hline Wall heating panels with heat pipes for $m=47.6 \mathrm{~g} / \mathrm{s}$ and $t 1=65^{\circ} \mathrm{C}, t_{\text {room }}=25^{\circ} \mathrm{C}$ & 93.8 & $+43 \%$ \\
\hline Wall heating panels with heat pipes for $m=10 \mathrm{~g} / \mathrm{s}$ and $t 1=65^{\circ} \mathrm{C}, t_{\text {room }}=25^{\circ} \mathrm{C}$ & 75.6 & $+15 \%$ \\
\hline Wall heating panels with heat pipes for $m=47.5 \mathrm{~g} / \mathrm{s}$ and $t 1=35^{\circ} \mathrm{C}, t_{\text {room }}=25^{\circ} \mathrm{C}$ & 22.9 & $-65 \%$ \\
\hline Wall heating panels with heat pipes for $m=10 \mathrm{~g} / \mathrm{s}$ and $t 1=35^{\circ} \mathrm{C}, t_{\text {room }}=25^{\circ} \mathrm{C}$ & 16.9 & $-74 \%$ \\
\hline $\begin{array}{l}\text { Floor heating system, taking into account maximum temperature of the floor }= \\
\qquad 29^{\circ} \mathrm{C} \text { (from the hygienic reasons), } t_{\text {room }}=20^{\circ} \mathrm{C}\end{array}$ & $<100$ & $+52 \%$ \\
\hline $\begin{array}{l}\text { Water-type wall heater, assumed maximum temperature of the surface: } 40^{\circ} \mathrm{C} \text {, } \\
\qquad t_{\text {room }}=20^{\circ} \mathrm{C}\end{array}$ & $\cong 250$ & $+280 \%$ \\
\hline Panel radiator type $11,300 \mathrm{~mm} \times 600 \mathrm{~mm}, t_{\mathrm{in}} / t_{\text {out }} / t_{\text {room }}=75 / 65 / 20^{\circ} \mathrm{C}$ & 1822 & $+2669 \%$ \\
\hline Panel radiator type $11,300 \mathrm{~mm} \times 600 \mathrm{~mm}, t_{\text {in }} / t_{\text {out }} / t_{\text {room }}=55 / 45 / 20^{\circ} \mathrm{C}$ & 1317 & $+1902 \%$ \\
\hline Panel radiator type $22,600 \mathrm{~mm} \times 1200 \mathrm{~mm}, t_{\text {in }} / t_{\text {out }} / t_{\text {room }}=75 / 65 / 20^{\circ} \mathrm{C}$ & 2849 & $+4230 \%$ \\
\hline Panel radiator type $22,600 \mathrm{~mm} \times 1200 \mathrm{~mm}, t_{\text {in }} / t_{\text {out }} / t_{\text {room }}=55 / 45 / 20^{\circ} \mathrm{C}$ & 1440 & $+2088 \%$ \\
\hline
\end{tabular}

The comparison shows that the specific thermal power of the investigated heating panels with pipes is lower than for the other systems. The highest differences are between investigated panels and traditional panel radiators, of which the specific thermal power is 19-27 times higher. When comparing the tested wall panel system with a similar floor or wall heating system, the differences are much smaller-at the level of $52 \%$ or $280 \%$, correspondingly. It has to be underlined that the experiment conducted in this paper was done for internal air temperature $t_{\text {room }}=25^{\circ} \mathrm{C}$ and the specific thermal power of the radiant panels, floor heating and wall heating systems is given for $t_{\text {room }}=20^{\circ} \mathrm{C}$. It can be estimated that reducing the room temperature would increase the difference between the surface temperature of the tested panels and the air temperature in the room, and thus, increase the thermal efficiency of the panels. However, it is difficult to estimate by what value. Conducting further tests for lower air temperatures inside the test chamber will be the subject of further tests and analyses.

It has to be noted that supplied water at temperatures of $65{ }^{\circ} \mathrm{C}$ cannot be treated as a low temperature system anymore. Nevertheless, the experiment was conducted for a wide range of water temperatures to capture the thermal characteristics of the system. It can be remarked that in the case of climates where minimal outside temperature during the heating season occurs rarely and short-term, the usage of such higher temperature of supplying water can be justified to not oversize the heating panel system and obtaining high energy efficiency during most of the heating season (except for brief periods of the lowest outdoor temperatures).

From a practical point of view, this type of wall-heating system has the advantage that water does not flow through the wall layer (the panels are fed from below through pipes located at the floor). This makes the installation of paintings, shelves and other interior items more secure in terms of possible flooding of the apartment with water. The heat pipes in these panels take up a much smaller surface area than the pipes in water systems, which makes them harder to hit. Heat pipes are also made of steel, much more durable than typical wall systems made of PE polyethylene or polypropylene PP pipes. On the other hand, in the event of their damage (which is quite unlikely), it is necessary to replace the entire panel, which will involve the demolition of the wall. At the same 
time, it is then associated with the leakage of R134a refrigerant. However, this is a small load that is completely harmless to human health.

It has to be noticed that the Global Warming Potential (GWP) of refrigerant R134a is 1430, which makes it harmful to the environment. Although the R134a is recommended by ASHRAE (AmericanSociety of Heating, Refrigerating and Air-Conditioning Engineers, Peachtree Corners, GA, USA) as aa replacement for refrigerants such as R12, R13 or R22, it is only recommended for use in the short term, as this makes it less harmful, but not sufficiently in long-time view of the deepening greenhouse effect. Suggested substitutes for R134a with a lower GWP value include: R1234yf, R1234ze, R513A, R450A and R600a. It has to be noted that although R134a can be harmful for the environment, the probability of its release from the heat pipes installed in the tested heating panel is negligible. Nevertheless, in future work, panels with heat pipes filled with refrigerants characterized by low GWP, such as R1234yf, R1234ze, R152a, R717 and R170, should be investigated. In Figure 8, the GWP of various refrigerants are presented to show the background of the usage of 134a in the context of eco-friendly buildings.

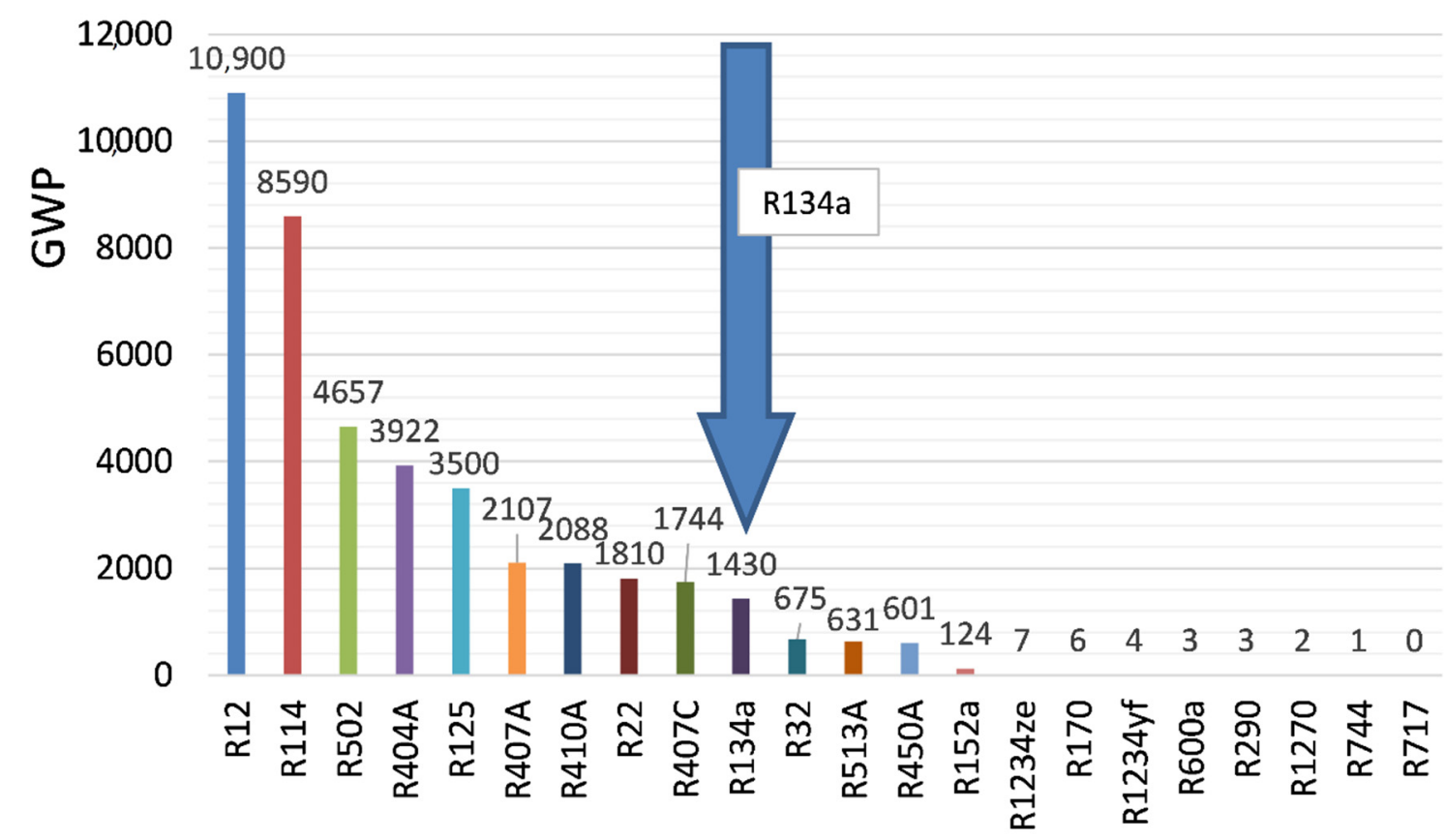

Figure 8. Review of the Global Warming Potential (GWP) values for various refrigerants using the producers' data.

From the economy point of view, currently, the cost of producing this type of heater is much greater than that of traditional water heaters and greater than that of other wall or floor heating systems. As it is a niche product, however, it is difficult to make a fair price comparison, as the price could change significantly if the system became popular and the is mass-produced.

\subsection{Limitations of the Study and Future Work}

These research results are one of the stages of work on the analysis of the thermal characteristics of wall plate heating systems with heat pipes. It should be emphasized that only one selected panel structure was tested in this study, and tests were carried out for one air temperature in the test chamber. This decision was motivated by the willingness to conduct an analysis of the sensitivity of the thermal performance of tested panels to changes in the operating parameters: the mass flowrate of heating water and its temperature. 
Further tests are planned to be performed at a different internal air temperature-the research will be aimed at determining the relationship between the thermal performance of the panel at different ambient temperatures - and for panels with heat pipes filled with other types of refrigerants.

The relationship between the supply water temperature and the panel surface temperature is also puzzling. It is not as obvious as for wall water loops. It will depend on the type of refrigerant used in the heat pipes, as well as its pressure and the geometric parameters of the heat pipes themselves. Moreover, indicative IR photos (Figure 9) show that the temperature distribution on the surface of this type of panel is not uniform. How it influences the heat transfer coefficient on the surface of the panel will be taken into account in future research. Additionally, the repeatability of panel production is also not perfect, which affects about $12 \%$ dispersion of the thermal power of the tested panels. More in-depth IR analysis will help in determining the average temperature of the panel surface and will enable the determination of average total and convective heat transfer coefficients.
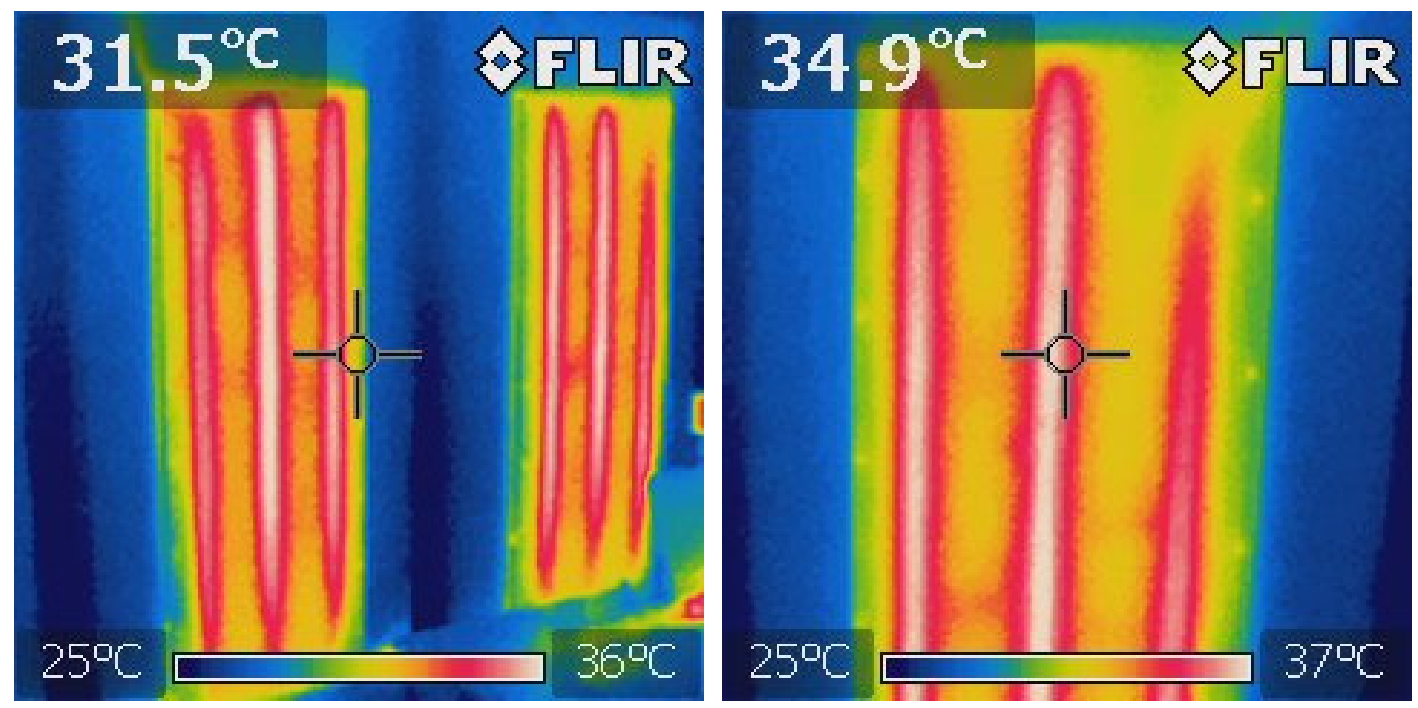

Figure 9. IR photos of the investigated panel during the experiment in a heating mode for the case: $t 1=55^{\circ} \mathrm{C}, m=47.5 \mathrm{~g} / \mathrm{s}, q_{\mathrm{m}}=71 \mathrm{~W} / \mathrm{m}^{2}$. On the left picture, one can see panel number 2 and 1 , on the right picture, panel number 1 .

The results presented in this study revealed the lack of perfect reproducibility of the production of panels, the thermal efficiency of which differs by up to $12 \%$ (it can be seen in Figure 9 that the first heat pipe in panel number 1 is not fully heated on the top). From an engineering point of view, this is not a discrepancy that disqualifies the panels; however, this observation prompts a deeper reflection on the very structure of panels and heat pipes. The influence of the type of refrigerant and its pressure on the thermal efficiency of the panels seems to be of particular interest.

Moreover, it should be emphasized that the tests were performed in a test chamber-in laboratory conditions. In fact, it would be impossible to mount the panels on the wall with $15 \mathrm{~cm}$ insulation around the panels. It is, therefore, to be expected that this would cause some of the heat to be conducted to the building envelope on which the panel would be mounted and reduce its thermal flux transferred via the front panel of the heater. For this reason, an interesting topic of future work seems to be in situ experimental research in a real building, for a real room and under conditions similar to the typical operating conditions of these devices.

Further research will be aimed at determining dependencies that will allow to generalize the thermal characteristics of various structures of this type of wall panel. Another experimental investigation is planned to be prepared in order to validate the numerical model of heat transfer that occurs in such types of heating panels. 


\section{Conclusions}

The conclusions that can be drawn from the presented research in the context of controlling the efficiency of wall panels with heat pipes are as follows:

- The specific heating power of the panel varies from $16.9 \mathrm{~W} / \mathrm{m}^{2}$ to $93.8 \mathrm{~W} / \mathrm{m}^{2}$ for supplying water temperatures ranging from $35^{\circ} \mathrm{C}$ to $65^{\circ} \mathrm{C}$ and a mass flowrate from $10 \mathrm{~g} / \mathrm{s}$ to $47.5 \mathrm{~g} / \mathrm{s}$,

- The obtained heating power is sufficient for heating low-energy buildings (i.e., nZEB) using the available surface of external or external and internal walls,

- The thermal performance of the panel is more sensitive to the changes of temperature than to the changes of mass flowrate of the supplied water,

- An increase of the water mass flowrate by $375 \%$ for the lowest supply water temperature $35^{\circ} \mathrm{C}$ resulted in an insignificant increase of specific thermal power by $6.0 \mathrm{~W} / \mathrm{m}^{2}$ for purposes of building heating; an analogous increase in the case of supply water temperature $65^{\circ} \mathrm{C}$ was $18.2 \mathrm{~W} / \mathrm{m}^{2}$,

- The investigated wall-type panels with heat pipes should be controlled mainly by the changing of the supply water temperature at low mass flowrates, which are conducive to achieving low flow resistance, and thus, lower electricity consumption to drive central heating circulation pumps.

This study presents experimental investigations of a novel radiant heating panel with heat pipes. Such systems have not been investigated in the literature yet. Their uniqueness lies in the replacement of the water loop heating the heating surface with heat pipes that transfer heat from hot water from the heat source to the heating surface. The conducted research has shown that the temperature drop on a single panel is relatively small $(0.1-2.0 \mathrm{~K})$ and depends mainly on the mass flow of the flowing heating water. The results gave an answer to the question of how to best control the heating performance of the panels: by changing the temperature of the supply water rather than by changing its flow rate. An increased flowrate causes a significant increase in pressure losses, with a simultaneous, relatively small increase in the specific thermal power of panel. Taking into account the results of this research, further studies are planned to better understand the properties of wall heating systems with heat pipes, namely, their thermal characteristics and relation between supply water temperature, specific thermal power and surface temperature. The analysis presented in the discussion of this paper shows that an interesting issue worth investigating is the possibility of using a different refrigerant filling heat pipes, the Global Warming Potential (GWP) of which will be lower than for the currently used R134a $(\mathrm{GWP}=1430)$.

Funding: This research was supported by the Ministry of Science and Higher Education in Poland, Grant No.504101/0713/SBAD/0940 and 504101/0713/SBAD/0935. The APC was funded by the Ministry of Science and Higher Education in Poland, Grant No. 504101/0713/SBAD/0940.

Acknowledgments: I would like to thank Fabian Cybichowski, didactic employee of the Institute of Environmental Engineering and Building Services, Poznan University of Technology and Adam Michalak, technical employee of the Institute of Environmental Engineering and Building Services, Poznan University of Technology, for the technical support provided during the construction of the measuring set-up.

Conflicts of Interest: The author declares no conflict of interest. The funders had no role in the design of the study; in the collection, analyses or interpretation of data; in the writing of the manuscript, or in the decision to publish the results.

\section{References}

1. Santamouris, M. Cooling the buildings-Past, present and future. Energy Build. 2016, 128, 617-638. [CrossRef]

2. Bandurski, K.; Bandurska, H.; Kazimierczak-Grygiel, E.; Koczyk, H. The Green Structure for Outdoor Places in Dry, Hot Regions and Seasons-Providing Human Thermal Comfort in Sustainable Cities. Energies 2020, 13, 2755. [CrossRef]

3. Ratajczak, K.; Amanowicz, Ł.; Szczechowiak, E. Assessment of the air streams mixing in wall-type heat recovery units for ventilation of existing and refurbishing buildings toward low energy buildings. Energy Build. 2020, 227, 110427. [CrossRef] 
4. Amanowicz, $€$. Influence of geometrical parameters on the flow characteristics of multi-pipe earth-to-air heat exchangers-Experimental and CFD investigations. Appl. Energy 2018, 226, 849-861. [CrossRef]

5. Amanowicz, Ł.; Wojtkowiak, J. Validation of CFD model for simulation of multi-pipe earth-to-air heat exchangers (EAHEs) flow performance. Therm. Sci. Eng. Prog. 2018, 5, 44-49. [CrossRef]

6. Cholewa, T.; Balen, I.; Siuta-Olcha, A. On the influence of local and zonal hydraulic balancing of heating system on energy savings in existing buildings-Long term experimental research. Energy Build. 2018, 179, 156-164. [CrossRef]

7. Cholewa, T.; Siuta-Olcha, A.; Balaras, C.A. Actual energy savings from the use of thermostatic radiator valves in residential buildings-Long term field evaluation. Energy Build. 2017, 151, 487-493. [CrossRef]

8. Dudkiewicz, E.; Jadwiszczak, P.; Jeżowiecki, J. Examination of operational dynamics of radiant ceiling panel. Cent. Eur. J. Eng. 2011, 1, 159-167. [CrossRef]

9. Życzyńska, A.; Suchorab, Z.; Majerek, D. Influence of Thermal Retrofitting on Annual Energy Demand for Heating in Multi-Family Buildings. Energies 2020, 13, 4625. [CrossRef]

10. Basińska, M.; Koczyk, H.; Szczechowiak, E. Sensitivity analysis in determining the optimum energy for residential buildings in Polish conditions. Energy Build. 2015, 17, 307-318. [CrossRef]

11. Basińska, M.; Koczyk, H.; Kosmowski, A. Assessment of Thermo-modernization Using the Global Cost Method. Energy Procedia 2015, 78, 2040-2045. [CrossRef]

12. Zhang, C.; Pomianowski, M.; Heiselberg, P.K.; Yu, T. A review of integrated radiant heating/cooling with ventilation systems-Thermal comfort and indoor air quality. Energy Build. 2020, 223, 110094. [CrossRef]

13. Dudkiewicz, E.; Szałański, P.K. Overview of exhaust gas heat recovery technologies for radiant heating systems in large halls. Therm. Sci. Eng. Prog. 2020, 18, 1005221. [CrossRef]

14. Park, B.; Ryu, S.R.; Cheong, C.H. Thermal Comfort Analysis of Combined Radiation-Convection Floor Heating System. Energies 2020, 13, 1420. [CrossRef]

15. Cholewa, T.; Rosiński, M.; Spik, Z.; Dudzińska, M.R.; Siuta-Olcha, A. On the heat transfer coefficients between heated/cooled radiant floor and room. Energy Build. 2013, 66, 599-606. [CrossRef]

16. Cholewa, T.; Anasiewicz, R.; Siuta-Olcha, A.; Skwarczynski, M.A. On the heat transfer coefficients between heated/cooled radiant ceiling and room. Appl. Therm. Eng. 2017, 117, 76-84. [CrossRef]

17. Kim, D.-W.; Joe, G.-S.; Park, S.-H.; Yeo, M.-S.; Kim, K.-W. Experimental Evaluation of the Thermal Performance of Raised Floor Integrated Radiant Heating Panels. Energies 2017, 10, 1632. [CrossRef]

18. Zheng, C.; You, S.; Zhang, H.; Liu, Z.; Zheng, W.; Wu, Z.; Fan, M. Defrosting Performance Improvement of Air-Source Heat Pump Combined Refrigerant Direct-Condensation Radiant Floor Heating System with Phase Change Material. Energies 2020, 13, 4594. [CrossRef]

19. Sinacka, J.; Szczechowiak, E. Heat Flow Modelling in a Building with Thermally Activated Building Systems. Ciepłownictwo Ogrzewnictwo Wentylacja 2018, 49, 271-278. (In Polish) [CrossRef]

20. Wojtkowiak, J.; Amanowicz, Ł.; Mróz, T. A new type of cooling ceiling panel with corrugated surface-Experimental investigation. Int. J. Energy Res. 2019, 43, 7275-7286. [CrossRef]

21. Lee, W.; Lim, T.; Kim, D.D. Thermal and Energy Performance Assessment of the Prefab Electric Ondol System for Floor Heating in a Residential Building. Energies 2020, 13, 5723. [CrossRef]

22. Ferrarini, G.; Fortuna, S.; Bortolin, A.; Cadelano, G.; Bison, P.; Peron, F.; Romagnoni, P. Numerical Model and Experimental Analysis of the Thermal Behavior of Electric Radiant Heating Panels. Appl. Sci. 2018, 8, 206. [CrossRef]

23. Lim, H.; Jeong, J.-W. Numerical and Experimental Study on the Performance of Thermoelectric Radiant Panel for Space Heating. Materials 2020, 13, 550. [CrossRef] [PubMed]

24. Echarri-Iribarren, V.; Rizo-Maestre, C.; Sanjuan-Palermo, J.L. Underfloor Heating Using Ceramic Thermal Panels and Solar Thermal Panels in Public Buildings in the Mediterranean: Energy Savings and Healthy Indoor Environment. Appl. Sci. 2019, 9, 2089. [CrossRef]

25. Ding, P.; Li, Y.; Long, E.; Zhang, Y.; Liu, Q. Study on heating capacity and heat loss of capillary radiant floor heating systems. Appl. Therm. Eng. 2020, 165, 114618. [CrossRef]

26. Cho, J.; Park, B.; Lim, T. Experimental and numerical study on the application of low-temperature radiant floor heating system with capillary tube: Thermal performance analysis. Appl. Therm. Eng. 2019, 163, 114360. [CrossRef]

27. Weibin, K.; Min, Z.; Xing, L.; Xiangzhao, M.; Lianying, Z.; Wangyang, H. Experimental Investigation on a Ceiling Capillary Radiant Heating System. Energy Procedia 2015, 75, 1380-1386. [CrossRef] 
28. Dong, J.; Zheng, W.; Ran, Z.; Zhang, B. Experimental investigation on heating performance of a novel radiant-convective heating terminal. Renew. Energy 2021, 164, 804-814. [CrossRef]

29. Dong, J.; Zhang, L.; Deng, S.; Yang, B.; Huanga, S. An experimental study on a novel radiant-convective heating system based on air source heat pump. Energy Build. 2018, 158, 812-821. [CrossRef]

30. Jouhara, H.; Almahmoud, S.; Chauhan, A.; Delpech, B.; Nannou, T.; Tassou, S.A.; Llera, R.; Lago, F.; Arribas, J.J. Experimental investigation on a flat heat pipe heat exchanger for waste heat recovery in steel industry. Energy Procedia 2017, 123, 329-334. [CrossRef]

31. Almahmoud, S.; Jouhara, H. Experimental and theoretical investigation on a radiative flat heat pipe heat exchanger. Energy 2019, 174, 972-984. [CrossRef]

32. Brough, D.; Mezquita, A.; Ferrer, S.; Segarra, C.; Chauhan, A.; Almahmoud, S.; Khordehgah, N.; Ahmad, L.; Middleton, D.; Sewell, H.I.; et al. An experimental study and computational validation of waste heat recovery from a lab scale ceramic kiln using a vertical multi-pass heat pipe heat exchanger. Energy 2020, 208, 118325. [CrossRef]

33. Delpech, B.; Milani, M.; Montorsi, L.; Boscardin, D.; Chauhan, A.; Almahmoud, S.; Axcell, B.; Jouhara, H. Energy efficiency enhancement and waste heat recovery in industrial processes by means of the heat pipe technology: Case of the ceramic industry. Energy 2018, 158, 656-665. [CrossRef]

34. Jouhara, H.; Meskimmon, R. An investigation into the use of water as a working fluid in wraparound loop heat pipe heat exchanger for applications in energy efficient HVAC systems. Energy 2018, 156, 597-605. [CrossRef]

35. Yau, Y.H. Application of a heat pipe heat exchanger to dehumidification enhancement in a HVAC system for tropical climates-A baseline performance characteristics study. Int. J. Therm. Sci. 2007, 46, 164-171. [CrossRef]

36. Yau, Y.H. Experimental thermal performance study of an inclined heat pipe heat exchanger operating in high humid tropical HVAC systems. Int. J. Refrig. 2007, 30, 1143-1152. [CrossRef]

37. Mahajan, G.; Thompson, S.M.; Cho, H. Experimental characterization of an n-pentane oscillating heat pipe for waste heat recovery in ventilation systems. Heliyon 2018, 4, e00922. [CrossRef]

38. Shafieian, A.; Khiadani, M.; Nosrati, A. Thermal performance of an evacuated tube heat pipe solar water heating system in cold season. Appl. Therm. Eng. 2019, 149, 644-657. [CrossRef]

39. Mehmood, A.; Waqas, A.; Said, Z.; Rahman, S.M.A.; Akram, M. Performance evaluation of solar water heating system with heat pipe evacuated tubes provided with natural gas backup. Energy Rep. 2019, 5, 1432-1444. [CrossRef]

40. Moss, R.W.; Henshall, P.; Arya, F.; Shire, G.S.F.; Hyde, T.; Eames, P.C. Performance and operational effectiveness of evacuated flat plate solar collectors compared with conventional thermal, PVT and PV panels. Appl. Energy 2018, 216, 588-601. [CrossRef]

41. Shafieian, A.; Osman, J.J.; Khiadani, M.; Nosrati, A. Enhancing heat pipe solar water heating systems performance using a novel variable mass flow rate technique and different solar working fluids. Sol. Energy 2019, 186, 191-203. [CrossRef]

42. Maraj, A.; Londo, A.; Gebremedhin, A.; Firat, C. Energy performance analysis of a forced circulation solar water heating system equipped with a heat pipe evacuated tube collector under the Mediterranean climate conditions. Renew. Energy 2019, 140, 874-883. [CrossRef]

43. Daniels, J.W., III; Heymsfield, E.; Kuss, M. Hydronic heated pavement system performance using a solar water heating system with heat pipe evacuated tube solar collectors. Sol. Energy 2019, 179, 343-351. [CrossRef]

44. Guichet, V.; Khordehgah, N.; Jouhara, H. Experimental investigation and analytical prediction of a multi-channel flat heat pipe thermal performance. Int. J. Thermofluids 2020, 5-6, 100038. [CrossRef]

Publisher's Note: MDPI stays neutral with regard to jurisdictional claims in published maps and institutional affiliations. 